\title{
Experimental behaviour of very high-strength concrete-encased steel composite column subjected to axial compression and end moment
}

\author{
Z. Huang ${ }^{a *}$, X. Huang ${ }^{a}$, W. Lia, Y. Zhou ${ }^{a}$, L. Sui ${ }^{a}$ and J. Y. Richard Liew \\ ${ }^{a}$ College of Civil Engineering, Shenzhen University, Shenzhen 518060, China \\ ${ }^{\mathrm{b}}$ Department of Civil and Environmental Engineering, National University of Singapore, 117576, Singapore \\ *corresponding author, e-mail address: huangzhenyu@szu.edu.cn
}

\begin{abstract}
A type of cost-effective and very high strength concrete (VHSC) with 28-day compressive strength of 100-150 MPa is developed for applications in concrete-encased steel composite column constructions. This paper experimentally investigates the structural behaviour of VHSC encased steel composite columns based on a series of pure compression and eccentric compression tests. It is found that such high-strength composite column exhibits brittle post peak behaviour and low ductility but with acceptable compressive resistance. Throughout the tests, the main failure of VHSC encased column under compressive load is brittle spalling of concrete followed by local buckling of the reinforcement bars. The splitting and slippage may occur between concrete and steel section due to bending downward action. The confinement effect by the shear stirrups designed based on normal reinforced concrete codes may not be sufficient. Composite column subjected to initial flexural cracking due to end moment load with large eccentricity may experience degradation in the stiffness and ultimate resistance so that plastic design resistance may not be achieved. Analytical studies show that the N-M interaction model based on current design codes may over-predict the combined resistance of the composite columns. Therefore, a modified elastic-plastic design approach based on strain compatibility is developed to evaluate the compressive resistance of concrete encased composite columns. The validation against the test data shows a reasonable and conservative estimation on the combined resistance of VHSC encased composite columns.
\end{abstract}

Keywords: composite column; concrete-encased column; high-strength concrete; steelconcrete composite.

\section{Introduction}

Concrete encased composite column is the use of steel section which is fully encased by concrete where they act together to provide higher load resistance. The use of encased section reduces the volume to strength ratio and provides superior fire resistance as well as the prevention of local buckling of steel section. Concrete encased composite column is more effective construction member with very high compressive resistance and good ductility. To maximize the merits of the concrete-encased steel composite column, the lately efforts have taken to the application of high strength material, e.g., high strength structural concrete and steel.
Structural concrete can be classified as normal strength concrete (NSC), high strength concrete (HSC), very high strength concrete (VHSC) and ultra-high strength concrete (UHSC), as listed in Table 1 [1]. The development of high strength concrete is a major progress in concrete technology due to its superior advantages such as high strength, high abrasion, low permeability and facilitating design of smaller structural sections with architectural and economic considerations. Such advantages enable a wide range of potential engineering application of high strength concrete. 
Table 1. Concrete strength classification.

\begin{tabular}{lcccc}
\hline Items & NSC & HSC & VHSC & UHSC \\
\hline $\begin{array}{l}\text { Strength } \\
\text { (MPa) }\end{array}$ & $<50$ & $50-100$ & $100-150$ & $>150$ \\
$\begin{array}{l}\text { Water- } \\
\text { cement ratio }\end{array}$ & $>0.45$ & $\begin{array}{c}0.45- \\
0.3\end{array}$ & $0.3-0.25$ & $<0.25$ \\
$\begin{array}{l}\text { Chemical } \\
\text { admixtures }\end{array}$ & No & $\begin{array}{c}\text { HRA/ } \\
*\end{array}$ & HRWR & HRWR \\
$\begin{array}{l}\text { Mineral } \\
\text { admixtures }\end{array}$ & No & Fly ash & $\begin{array}{l}\text { Silica } \\
\text { fume }\end{array}$ & Silica \\
$\begin{array}{l}\text { Permeabilit } \\
\text { y coefficient } \\
\text { (cm/s) }\end{array}$ & $>10^{-10}$ & $10^{-11}$ & $10^{-12}$ & $<10^{-13}$ \\
$\begin{array}{l}* \text { WRA= water reducing admixture; HRWR }=\text { high- } \\
\text { range water reducer. }\end{array}$ & & &
\end{tabular}

Nowadays, there are design codes such as AIJ [2], AISC 360 [3], Eurocode 4 [4], YB 90822006 [5] and JGJ 1382016 [6], which are available for concrete encased column design practice. However, currently there is no unified design theory among these codes while the current codes basically are limited for conventional strength concrete (e.g., 20$90 \mathrm{MPa})$. VHSC is a new class of concrete that may not be covered in current column design codes.

Generally, VHSC exhibits very brittle and large autogenous shrinkage behavior, which may lead to uncertainties in practical application and greatly influence the failure mechanism, ductility and energy dissipation behaviour of composite column. Therefore, it is quite significant to assess the structural performance of VHSC encased composite column. Kim et al. $[1,7-9]$ investigated the compressive behaviour of concrete encased composite column using ultra high strength concrete under eccentric loads. It was found that column with good confinement effect by using tie bar restraints show ductile behaviour, maintaining high strength even after crushing of concrete. Composite column using welded corner Lshaped section exhibits superior confinement behaviour although the concrete cover was severely spalled. Ellobody et al. [10, 11] investigated eccentrically loaded concrete encased composite column with varying concrete strength from $30-110 \mathrm{MPa}$ and steel yield strength from 275-690MPa numerically. It was shown that the EC4 accurately predicts the eccentrically loaded composite columns, while overestimated the moment.

In this paper, the mechanical behaviour of VHSC encased steel composite columns was experimentally investigated based on a series of pure compression and eccentric compression tests on short columns with/without rebar reinforcement. A modified elastic-plastic approach is developed to predict the compressive and bending resistance of VHSC encased columns based on the failure modes of the columns. The axial resistance vs moment resistance interaction diagrams are calculated and verified by current design codes as well as test data.

\section{Experimental programme}

\subsection{Material properties}

The concrete is designed to have a target 28day cylinder compressive strength around 50 $\mathrm{MPa}$ (C50) and $100 \mathrm{MPa}$ (C100), respectively. Three $100 \times 200 \mathrm{~mm}$ concrete cylinder coupons and three $100 \times 100 \mathrm{~mm}$ concrete cube coupons were tested for each mixture, according to ASTM C39/C39M-14 [12]. Table 2 lists the material properties of concrete.

Table 2. Material properties of concrete coupons.

\begin{tabular}{lcccc}
\hline Concrete & $\begin{array}{c}\boldsymbol{f}_{\text {ck }} \\
(\mathrm{MPa})\end{array}$ & $\begin{array}{c}\boldsymbol{f}_{\text {cube }} \\
(\mathrm{MPa})\end{array}$ & $\begin{array}{c}\boldsymbol{E}_{\boldsymbol{c}} \\
(\mathrm{GPa})\end{array}$ & $\boldsymbol{v}_{\boldsymbol{c}}$ \\
\hline $\mathrm{C} 50$ & 51.1 & 49.8 & 37.3 & \\
$\mathrm{C} 100$ & 109.3 & 109.0 & 44.9 & 0.25 \\
$\mathrm{C} 100 \mathrm{~F}$ & 123.8 & 130.4 & 47.6 & \\
\hline
\end{tabular}

Mild steel S355, HRB 400 rebar and HPB 400 stirrup were used for specimen fabrication. According to ASTM E8/E8M-16 [13], direct tension tests using a universal test machine were performed for the steel materials. Table 3 lists the material properties of steel plate, rebar and stirrup.

Table 3. Material properties of steel plate, rebar and stirrup.

\begin{tabular}{lcccc}
\hline Item & Component & $\begin{array}{c}\boldsymbol{E}_{\boldsymbol{s}} \\
(\mathrm{MPa})\end{array}$ & $\begin{array}{c}\boldsymbol{f}_{\boldsymbol{y}} \\
(\mathrm{MPa})\end{array}$ & $\boldsymbol{v}_{\boldsymbol{s}}$ \\
\hline $\begin{array}{l}\text { Steel } \\
\text { flange }\end{array}$ & Mile steel & 201.55 & 362.93 & \\
Steel web & Mile steel & 187.41 & 363.61 & 0.3 \\
Rebar & HRB 400Ø16 & 193.64 & 356.8 & \\
Stirrup & HPB 400Ø6 & 225.13 & 339.4 & \\
\hline
\end{tabular}




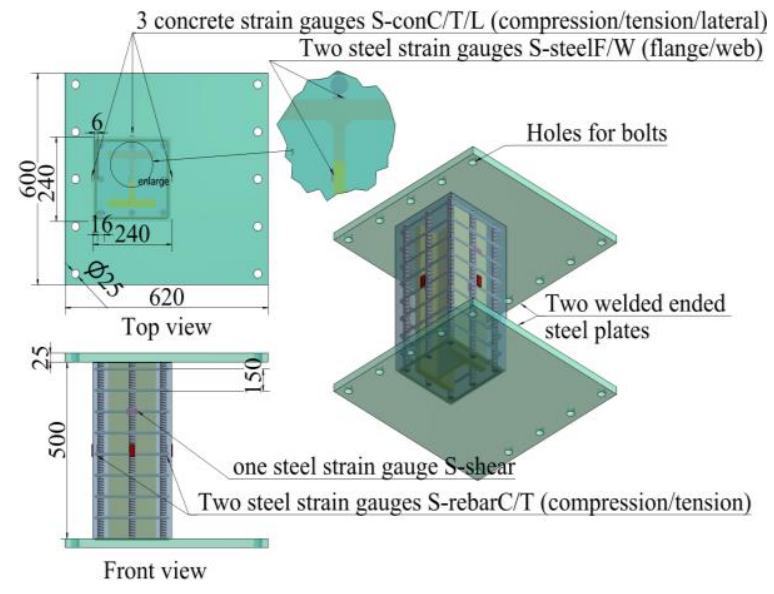

(a) Short column.

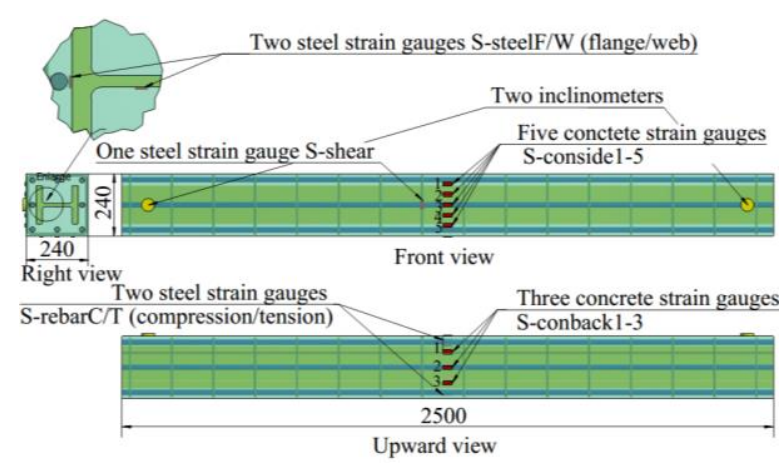

(b) Long column.

Fig. 1. Dimensions and strain gages layout.

\subsection{Design consideration}

A total of 6 composite column specimens were prepared. Fig. 1 shows the dimension and strain gauges layout of specimens. Test specimens (shown in Table 4) were made of a S355 steel section UC152X152X37 and a square size of $240 \times 240 \mathrm{~mm}$ was selected. The columns for loading with/without eccentricity were designed to behave as short columns with an overall height of $500 \mathrm{~mm}$. The relative slenderness ratio was $\lambda=0.14<2.0$ (according to Eurocode 4). Two cover plates were welded on both ends of the specimens in order to be loaded uniformly. The column for pure bending is designed to be $2500 \mathrm{~mm}$ long in order to capture the flexural resistance of composite column, while other geometrical conditions and material properties kept the same. The steel ratio is $8.18 \%$. The steel contribution ratio is $\delta=0.26$ $(0.2<\delta<0.9$, according to Eurocode 4$) .8$ rebars with a diameter of $16 \mathrm{~mm}$ were employed as longitudinal reinforcement. The rebar ratio is $1.54 \%(0.3 \%-6 \%$, according to Eurocode 4$)$. According to Eurocode 2 [14], spacing of 150 $\mathrm{mm}$ with a diameter of $6 \mathrm{~mm}$ is employed in the test.
Table 4. Detailed information of specimens.

\begin{tabular}{lcccc}
\hline Specimen & $\begin{array}{c}\boldsymbol{f}_{\boldsymbol{c}} \\
(\mathrm{MPa})\end{array}$ & $\begin{array}{c}\boldsymbol{f}_{\text {fiber }} \\
(\mathrm{MPa})\end{array}$ & $\begin{array}{c}\boldsymbol{f}_{\boldsymbol{s}} \\
(\mathrm{MPa})\end{array}$ & $\begin{array}{c}\boldsymbol{e} \\
(\mathrm{mm})\end{array}$ \\
\hline $\mathrm{C} 50 \mathrm{e} 0$ & 51.1 & - & 356.8 & 0 \\
$\mathrm{C} 100 \mathrm{e} 0$ & 109.3 & - & 356.8 & 0 \\
$\mathrm{C} 100 \mathrm{e} 50$ & 109.3 & - & 356.8 & 50 \\
$\mathrm{C} 100 \mathrm{e} 105$ & 109.3 & - & 356.8 & 105 \\
$\mathrm{C} 100 \mathrm{~B}$ & 109.3 & - & 356.8 & - \\
$\mathrm{C} 100 \mathrm{~F}$ & 123.8 & 1600 & - & 0 \\
\hline
\end{tabular}

\subsection{Test set-up and instrumentation}

Fig. 2 shows the test instrumentation and setup for compression test. A $10 \mathrm{MN}$ testing actuator operated in displacement-control mode was used to test the specimens. The supports included a cylinder that simulated a uniform load on the specimens. According to the previous literatures $[15,16]$, the boundary conditions of the column were pin-pin supported. Each specimen was instrumented with linear variable displacement transducers (LVDT), as shown in Fig. 2.

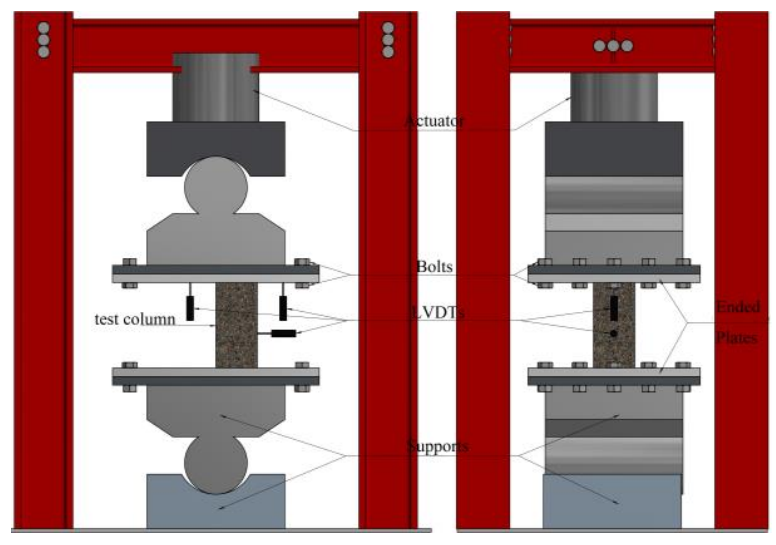

Fig. 2. Test setup and instrumentation.

\section{Test result and discussion}

\subsection{Typical failure modes}

Table 5 lists the failure loads and failure modes of the test specimens.

Fig. 3 depicts the failure condition of the specimens at the end of the test. It was found that the basic failure mode of VHSC encased steel composite column under compression with/without eccentricity was concrete spalling followed by local buckling of rebar, since the spalling concrete lose the bond resistance to the 
rebar and shear stirrups, inducing buckling of rebar. Normal strength specimen $(\mathrm{C} 50 \mathrm{e} 0)$ under pure compression failed by concrete crushing followed by yielding of reinforcement rebar. High strength concrete encased columns under pure compression or eccentric compression (C100e $0, \mathrm{C} 100 \mathrm{e} 50)$ generally failed by concrete spalling and yielding of rebar before the steel plates yielding, which indicated that the strength of steel plate was not fully mobilized as a result of insufficient confinement of concrete. In addition, breakage surface of concrete was smooth which implied concrete failed by shear failure. As the load eccentricity became larger (C100e105), significant curvature of the specimens was observed. The failure mode of specimen was governed by tension failure, which was controlled by tensile yielding of reinforced rebar accompanied with tensile cracking of concrete. As for specimen under pure bending (C100B), it failed by slippage between concrete and steel section followed by yielding of steel plate. The debonding of concrete may induce prefailure of composite section, resulting in unexpected lower moment resistance from the test. Vertical flexure cracks appeared within the pure bending region and diagonal shear cracks appeared at regions under combined shear and bending. However, with the use of fiber-reinforced concrete $(\mathrm{C} 100 \mathrm{~F})$, major failure mechanism is combined crushing and splitting of concrete. The addition of steel fiber can improve the compressive strength of concrete as well as tensile strength significantly and less cracks were observed.

Table 5. Failure loads and failure modes.

\begin{tabular}{|c|c|c|c|c|}
\hline Specimen & $\begin{array}{c}\mathbf{P} \\
(\mathrm{kN})\end{array}$ & $\underset{(\mathrm{kN} \cdot \mathrm{m})}{\mathbf{M}}$ & $\begin{array}{l}\text { Primary } \\
\text { failure }\end{array}$ & $\begin{array}{l}\text { Other } \\
\text { failure }\end{array}$ \\
\hline $\mathrm{C} 50 \mathrm{e} 0$ & 3744.1 & - & $\mathrm{CC}$ & LBR \\
\hline $\mathrm{C} 100 \mathrm{e} 0$ & 6913.4 & - & $\mathrm{CS}$ & LBR \\
\hline $\mathrm{C} 100 \mathrm{e} 50$ & 3686.7 & 242.8 & $\mathrm{CS}$ & LBR \\
\hline $\mathrm{C} 100 \mathrm{e} 105$ & 1800.5 & 209.7 & $\mathrm{TF}$ & $\mathrm{CC}$ \\
\hline C100B & 314.0 & 149.1 & $\mathrm{FF}$ & $\begin{array}{l}\text { SF, } \\
\text { CSl }\end{array}$ \\
\hline $\mathrm{C} 100 \mathrm{~F}$ & 7256.9 & - & $\mathrm{CSp}$ & $\mathrm{CS}$ \\
\hline
\end{tabular}

splitting; $\mathrm{LBR}=$ Local buckling of rebar; $\mathrm{SF}=$ Shear failure; $\mathrm{CSl}=$ concrete slippage.

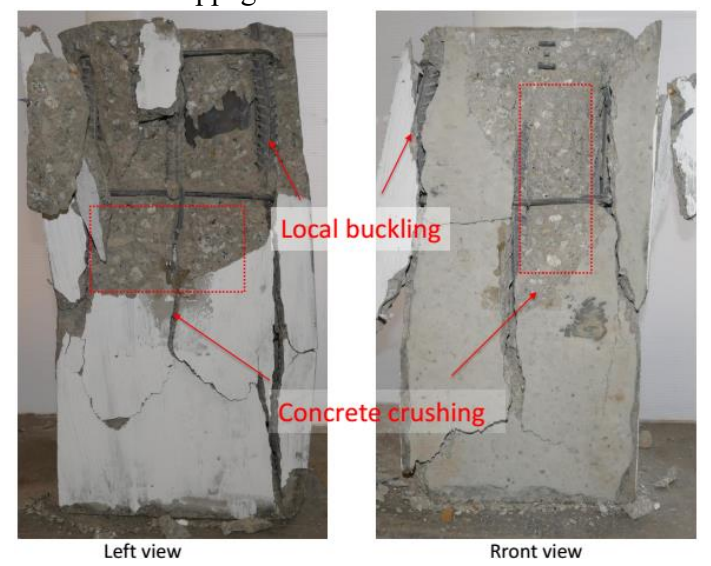

(a) $\mathrm{C} 50 \mathrm{e} 0$.

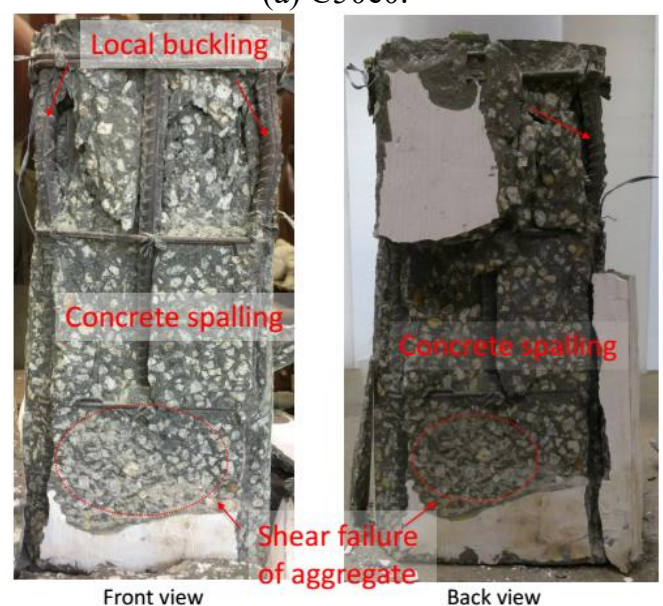

(b) $\mathrm{C} 100 \mathrm{e} 0$
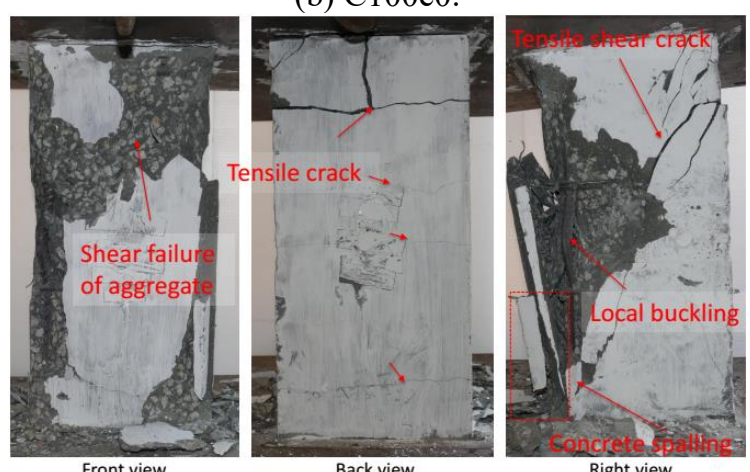

(c) $\mathrm{C} 100 \mathrm{e} 50$.
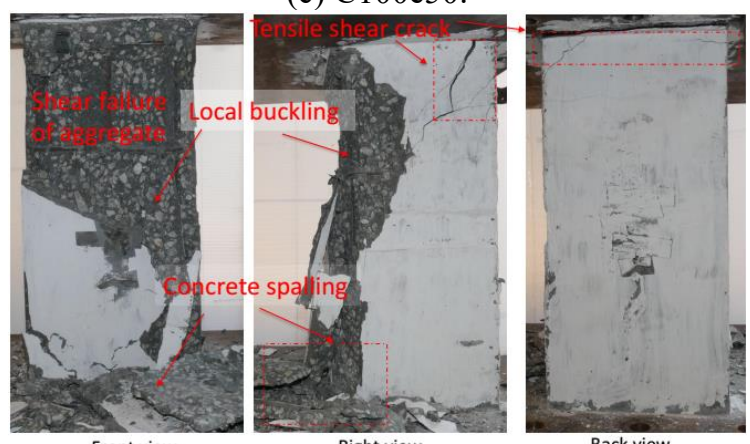

(d) C100e105. 


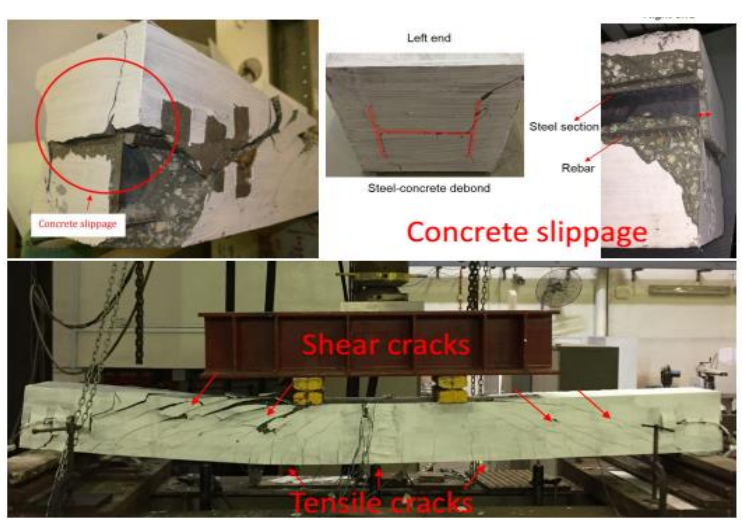

(e) C100B.
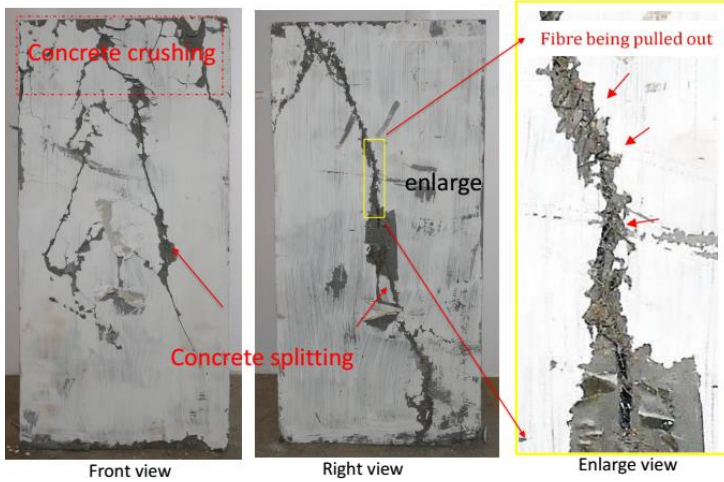

(f) $\mathrm{C} 100 \mathrm{~F}$.

Fig. 3. Failure modes of test specimens.

\subsection{Load-displacement relationship}

The load-displacement curves of all specimens are plotted in Fig. 4 and Fig. 5. For specimen $\mathrm{C} 50 \mathrm{e} 0$, the load-displacement curve can be characterized by an upwards trend reaching to the ultimate load followed by a slightly descending trend plateau. For C100eX series specimens, the ultimate pure compression resistance is significantly larger than specimen $\mathrm{C} 50 \mathrm{e} 0$, while the post-yield behaviour is more brittle than that of specimen $\mathrm{C} 50 \mathrm{e} 0$. For specimen $\mathrm{C} 100 \mathrm{~F}$, the ultimate compression resistance is much larger than that of $\mathrm{C} 50 \mathrm{e} 0$ and $\mathrm{C} 100 \mathrm{e} 0$. The load dramatically increases to the peak load followed a sudden drop to about two thirds of maximum load, and then regain the load with slightly smaller than the peak value. The sharp drop resulted from the pullout failure of steel fiber in concrete. Then the load was regained again owing to the residual strength of the steel plate section. The load-displacement curve of $\mathrm{C} 100 \mathrm{~B}$ is ductile with a turning point at $320 \mathrm{kN}$ due to the flexural cracks of bottom concrete and yielding of rebars, after which the strain developed rapidly.

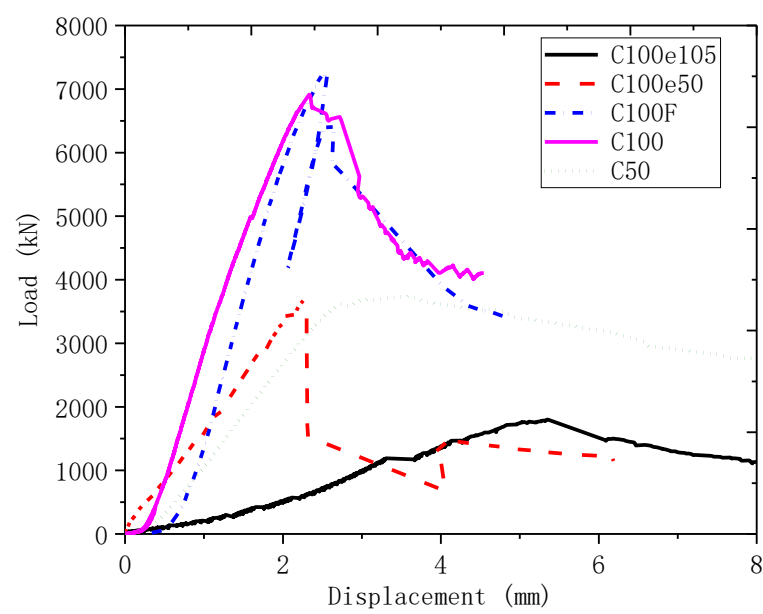

Fig. 4. Load-displacement curve for compression.

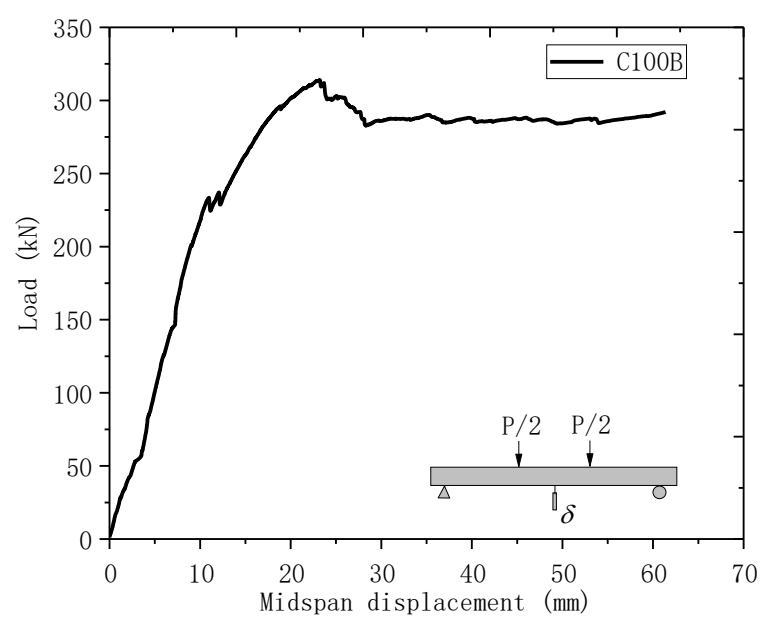

Fig. 5. Load-midspan displacement for bending.

\section{Analytical study}

\subsection{Elastic-plastic analysis}

The composite design based on current codes may not be sufficient for VHSC encased steel composite column. Hence, the plastic stress distribution of the section may not be achieved. Thus, an elastic-plastic analysis based on strain compatibility is carried out to obtain a more accurate and conservative prediction.

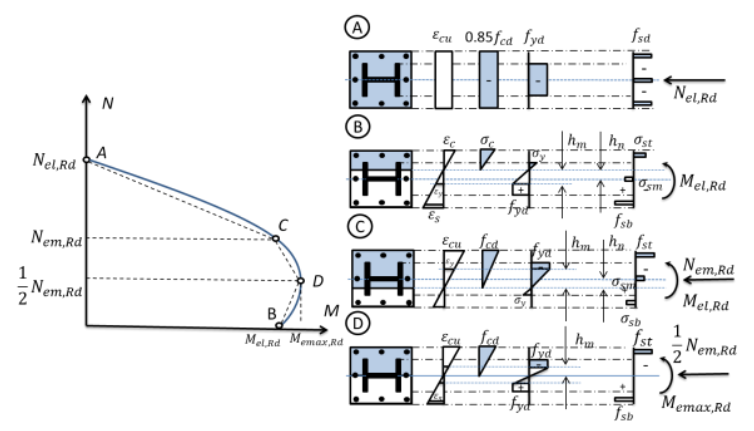

Fig. 6. Elastic-plastic stress distribution. 
Fig. 6 shows elastic-plastic stress distribution of column section based on following assumption: (a) triangular elastic stress blocks of concrete, (b) zero concrete tensile strength, (c) the strain-compatibility is fulfilled; (d) rebar stress is restricted within elastic stage; (e) the steel plate can achieve its plastic stress phase. Given the neutral axis distance $x_{c}$, the strain and stress of each component in the section is confirmed. Hence, each point on the N-M curve can be ascertain by solving the axial force and bending moment equilibrium equations of the whole section. To simplified the calculation procedure, numerical fiber sectional analysis method $[17,18]$ was employed to calculate the axial force and bending moment (Fig. 7). Using this method, the cross section is divided into long strips, where the constitutive relationships are based on the strain campaitibity and stress-strain relationship of each constituent materials. The calculation method of so-called elastic-plastic analysis is shown as Eq. (1).

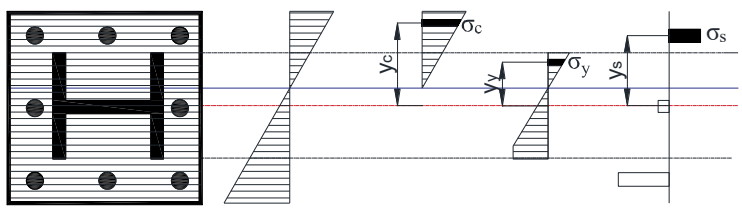

Fig. 7. Numerical fiber sectional analysis.

$$
\begin{aligned}
& N=\sum A_{c} \sigma_{c}+\sum A_{y} \sigma_{y}+\sum A_{s} \sigma_{s} \\
& M=\sum A_{c} \sigma_{c} y_{c}+\sum A_{y} \sigma_{y} y_{y}+\sum A_{s} \sigma_{s} y_{s}
\end{aligned}
$$

where $A_{c}, A_{y}$ and $A_{s}$ are the fiber element area of concrete segment, structural steel segment, and reinforced rebar segment, respectively; $\sigma_{c}, \sigma_{y}$ and $\sigma_{s}$ are the stress of concrete, structural steel and reinforced rebar, respectively, which can be calculate by $\sigma_{x}=E_{x} \cdot \varepsilon ; y_{c}, y_{y}$ and $y_{s}$ are distance from the fiber segment of concrete, structural steel and reinforced rebar to the $\mathrm{z}$ axis, respectively.

\subsection{Verification and discussion}

To verify the elastic-plastic analysis and evaluate the applicability of current codes to the composite column with VHSC, the test results were plotted in the N-M interation curves compared with data predicted by current design codes and elastic-plastic analysis method.(Fig. 8)

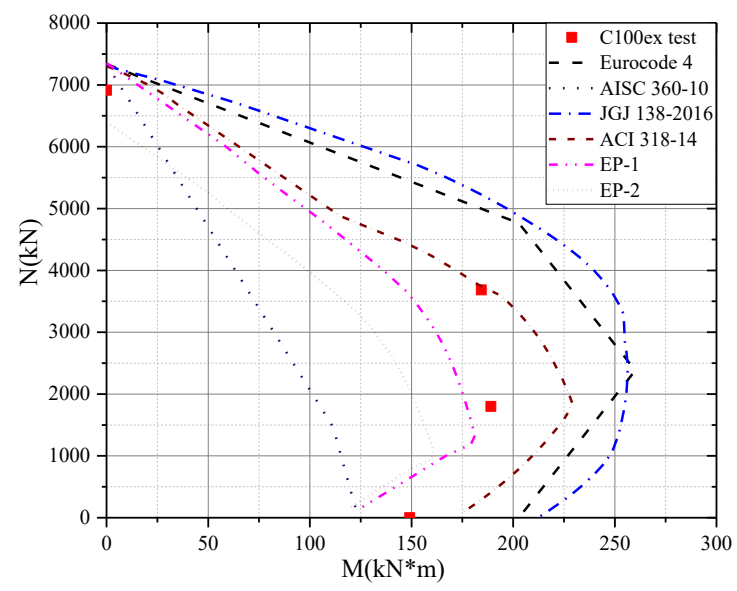

Fig. 8. Comparison of between test data and current methods.

All the partial factors in the specifications are taken as 1.0 for comparison. The Eurocode 4 and JGJ 138-2016, which use the plastic stress distribution, over-estimate the compressive resistance of the VHSC encased steel column, especially for the specimen loaded with large eccentricity. AISC 360-10 Method I is overconservative in prediction of $\mathrm{C} 100 \mathrm{e} 50$ with $45 \%$ smaller than the test value, while underestimate the flexural resistance in $\mathrm{C100B}$. The ACI 318-14 method, which utilizes the straincompatibility, well predicts the bending moment of composite column under compression with an eccentricity of $50 \mathrm{~mm}$. However, it overestimates the case with larger eccentricity due to that the ultimate strain of concrete is assumed as 0.003 and the block stress distribution of concrete is used regardless of the degree of concrete confinement. It is found that all the test data are outside the elastic analysis diagram, which indicates that the elastic analysis method can provide a relatively conservative prediction.

\section{Conclusions}

This paper presents experimental and analytical investigations of structural behaviour of VHSC encased steel composite columns subjected to axial compression and end moment. The following conclusions are derived based on the test and analytical investigations:

(1) The VHSC concrete encased composite columns exhibits brittle and explosive spalling failure mode under axial compression. Early spalling may result from the insufficient stirrups. The major failure mode observed from the tests was concrete spalling followed local buckling of longitudinal reinforcement. 
(2) Using steel fiber as substitution of reinforcement in VHSC has mobilized the steel strength, but the major failure of such composite column is still brittle due to the absence of confinement effect provided by the shear stirrups. However, the novel section is able to achieve the cross-sectional resistance, which indicates the rebar reinforcement may be reduced or even removed. Further study should conduct more investigation.

(3) For pure compression and eccentric compression, section plastic resistance can be achieved while for pure bending and compression with large eccentricity, section plastic resistance cannot be obtained. The plastic design approach for composite columns in current codes may over-predict the resistance of VHSC encased composite column. A modified $\mathrm{N}-\mathrm{M}$ interaction model based on the strain compatibility is developed to predict the combined resistance of composite column.

However, this study investigates the structural behaviour of VHSC encased composite column experimentally and analytically with limited parameters. Further study should extend to investigate a wider range of parameters, e.g., providing closer shear stirrups to confine the high strength concrete core, steel fiber content and type. Development of novel shear links could also be helpful to enhance the ductility performance of composite columns. Besides, partial shear interaction of the VHSC and steel plate in the case of pure bending needs to be further investigated [19].

\section{References}

[1] Kim C-S, Park H-G, Lee H-J, Choi I-R, Chung $\mathrm{K}-\mathrm{S}$. Eccentric axial load test for high-strength composite columns of various sectional configurations. Journal of Structural Engineering 2017; 143(8): 04017075.

[2] Structural Standard for RC Building. Standard for Structural Calculation of Steel Reinforced Concrete Structures. Tokyo; 2010.

[3] ANSI-AISC 360-10 Specification for Structural Steel Buildings. Chicago; 2010.

[4] Eurocode 4. Design of composite steel and concrete structures, Part1-1: general rules and rules for buildings. Brussels, Belgium; 2004.

[5] China Metallurgical Group Building Research Institute. YB 9082-2006. Technical specification of steel-reinforced concrete structures. Beijing: Metallurgical Industry Press; 2007.
[6] JGJ 138-2016 Code for design of composite structures. Beijing: the Chinese construction industry edition club; 2016.

[7] Kim CS, Park HG, Choi I-R, Chung K-S. Effect of sustained load on ultimate strength of highstrength composite columns using $800 \mathrm{MPa}$ steel and $100 \mathrm{MPa}$ concrete. Journal of Structural Engineering 2017; 143(3): 04016189.

[8] Kim C-S, Park H-G, Chung K-S, Choi I-R. Eccentric axial load testing for concrete-encased steel columns using $800 \mathrm{MPa}$ steel and $100 \mathrm{MPa}$ concrete. Journal of Structural Engineering. 2012; 138(8): 1019-31.

[9] Kim C-S, Park H-G, Chung K-S, Choi I-R. Eccentric axial load capacity of high-strength steel-concrete composite columns of various sectional shapes. Journal of Structural Engineering 2014; 140(4): 04013091.

[10] Ellobody E, Young B. Numerical simulation of concrete encased steel composite columns. Journal of Constructional Steel Research 2011; 67(2): 211-22.

[11] Ellobody E, Young B, Lam D. Eccentrically loaded concrete encased steel composite columns. Thin-Walled Structures 2011; 49(1): 53-65.

[12] ASTM C39/C39M-14a. Standard test method for compressive strength of cylindrical concrete specimens; 2014.

[13] ASTM E8 E8M. Standard test methods for tension testing of metallic materials. ASTM.

[14] Eurocode 2: Design of concrete structures, Part 1-1: general rules and rules for buildings. Brussels, Stassart; 2004.

[15] Huang Z, Liew JYR. Structural behaviour of steel-concrete-steel sandwich composite wall subjected to compression and end moment. Thin-Walled Structures 2016; 98: 592-606.

[16] Du Y, Chen Z, Wang Y-B, Richard Liew JY. Ultimate resistance behavior of rectangular concrete-filled tubular beam-columns made of high-strength steel. Journal of Constructional Steel Research 2017; 133: 418-33.

[17] El-Tawil S, Deierlein GG. Strength and ductility of concrete encased composite columns 1999; 125(9): 1009-19.

[18] Tokgoz S, Dundar C, Tanrikulu AK. Experimental behaviour of steel fiber high strength reinforced concrete and composite columns. Journal of Constructional Steel Research 2012; 74(1): 98-107

[19] Heidarpour A, Bradford MA. Generic nonlinear modelling of a bi-material composite beam with partial shear interaction. International Journal of Non-Linear Mechanics 2009; 44(3): 290-297. 